\title{
Impairment of mineralization by metavanadate and decavanadate solutions in a fish bone-derived cell line
}

\author{
Daniel M. Tiago • Vincent Laizé • \\ M. Leonor Cancela $\cdot$ Manuel Aureliano
}

Received: 20 April 2007 / Accepted: 23 August 2007 / Published online: 25 September 2007

(C) Springer Science + Business Media B.V. 2007

\begin{abstract}
Vanadium, a trace metal known to accumulate in bone and to mimic insulin, has been shown to regulate mammalian bone formation using in vitro and in vivo systems. In the present work, short- and long-term effects of metavanadate (containing monomeric, dimeric, tetrameric and pentameric vanadate species) and decavanadate (containing decameric vanadate species) solutions on the mineralization of a fish bone-derived cell line (VSa13) were studied and compared to that of insulin. After $2 \mathrm{~h}$ of incubation with vanadate $(10 \mu \mathrm{M}$ in monomeric vanadate), metavanadate exhibited higher accumulation rates than decavanadate $(6.85 \pm 0.40$ versus $3.95 \pm$ $0.10 \mu \mathrm{g} \mathrm{V} / \mathrm{g}$ of protein, respectively) in fish VSa13 cells and was also shown to be less toxic when applied for short periods. In longer treatments with
\end{abstract}

Daniel M. Tiago and Vincent Laizé1 contributed equally to this work.

D. M. Tiago $\cdot$ V. Laizé $\cdot$ M. L. Cancela $\cdot$ M. Aureliano

Centre of Marine Sciences (CCMAR),

University of Algarve, Campus Gambelas,

8005-139 Faro, Portugal

M. Aureliano $(\triangle)$

Faculdade de Ciências e Tecnologia (FCT),

Universidade do Algarve, Campus de Gambelas,

8005-139 Faro, Portugal

e-mail: maalves@ualg.pt both metavanadate and decavanadate solutions, similar effects were promoted: stimulation of cell proliferation and strong impairment $(75 \%)$ of extracellular matrix (ECM) mineralization. The effect of both vanadate solutions $(5 \mu \mathrm{M}$ in monomeric vanadate), on ECM mineralization was increased in the presence of insulin $(10 \mathrm{nM})$. It is concluded that chronic treatment with both vanadate solutions stimulated fish VSa13 cells proliferation and prevented ECM mineralization. Newly developed VSa13 fish cells appeared to be appropriate in the characterization of vanadate effects on vertebrate bone formation, representing a good alternative to mammalian systems.

Keywords Bone-derived cell line - Vanadate ·

Decavanadate $\cdot$ Insulin-mimetic properties .

Vertebrate bone formation - Teleost fish Sparus aurata

$\begin{array}{ll}\text { Abbreviations } \\ \text { DMEM } & \text { Dulbecco's modified Eagle medium } \\ \text { ECM } & \text { Extracellular matrix } \\ \text { ERK } & \text { Extracellular signal-regulated kinase } \\ \text { FBS } & \text { Fetal bovine serum } \\ \text { MAPK } & \text { Mitogen-activated protein kinase } \\ \text { MTS } & \text { (3-(4,5-dimethylthiazol-2-yl)-5- } \\ & \begin{array}{l}\text { (3-carboxy-methoxyphenyl)-2- } \\ \text { (4-sulfophenyl)-2H-tetrazolium }\end{array} \\ \text { PBS } & \text { Phosphate-buffered saline } \\ \text { PI3-K } & \text { Phosphatidyl inositol-3 kinase }\end{array}$




\section{Introduction}

Vanadium, an essential trace element found in animals and higher plants (Anke 2004) and described to be accumulated in mammalian bone (Etcheverry et al. 1984), has been shown to display important biological effects in association with its physicochemical properties, e.g. insulin-like activity and regulation of phosphatases and ATPases activity (Nielsen and Uthus 1990). Vanadium, which easily transitions between three oxidation states, namely, V(III), V(IV) and $\mathrm{V}(\mathrm{V})$, has been proposed to be potentially important for its role as a biometal (Rehder 1999, 2003). Vanadate $(\mathrm{V}(\mathrm{V}))$, which is the most stable oxidation state in aerobic conditions, forms in solution monomeric vanadate species with different states of protonation, such as $\mathrm{HVO}_{4}^{2-}$ or $\mathrm{H}_{2} \mathrm{VO}_{4}^{-}$, depending on $\mathrm{pH}$ value. However, at physiological $\mathrm{pH}$ values and at millimolar range of concentrations, several $n$-meric species $(n=1$ to 10$)$, normally ascribed as vanadate oligomers, can occur simultaneously in equilibrium, such as monomeric $\left(\mathrm{V}_{1}\right)$, dimeric $\left(\mathrm{V}_{2}\right)$ and tetrameric $\left(\mathrm{V}_{4}\right)$ vanadate species (Amado et al. 1993). Eventually, even decameric $\left(V_{10}\right)$ vanadate species can be formed upon medium acidification (Aureliano and Gândara 2005). These vanadate oligomers species have been shown to interact with several proteins, thus affecting many biological systems (Crans et al. 2004). For instance, monomeric vanadate as been described to behave as a phosphate analogue, inhibiting (or, in some cases, stimulating) several phosphatases (acid, alkaline and protein phosphatases), phosphorylases, ribonucleases and ATPases (Crans et al. 2004). Conversely, other vanadate oligomers, such as the decameric vanadate, has been described to inhibit non-competitively several enzymes, among others, proteins involved in muscle contraction and regulation such as myosin ATPase and sarcoplasmic reticulum calcium ATPase, thus contributing for the several biological processes influenced by vanadate (Aureliano and Madeira 1994; Tiago et al. 2004; Aureliano and Gândara 2005).

The most important clinical effect of vanadium is probably its ability to mimic or to enhance the effect of insulin, as demonstrated in various in vivo and in vitro studies using streptozocin-treated diabetic rats (Heyliger et al. 1985; Meyerovitch et al. 1987) and adipocyte cultures (Dubyak and Kleinzeller 1980; Shechter and Karlish 1980). Insulin, a peptide that binds to specific membrane tyrosine kinase receptors, initiates intracellular signalling that either results in the regulation of protein, lipid, carbohydrate and mineral metabolism, or cell differentiation and proliferation, depending on the involved pathways: phosphatidyl inositol-3 kinase (PI3-K) pathway for metabolic effects or mitogen-activated protein kinase (MAPK) pathway for cell proliferation and differentiation effects (Cheatham and Kahn 1995; Cohick and Clemmons 1993; LeRoith 2000). Vanadium insulinmimetic properties have been associated to the activity of tyrosine phosphatases and consequent activation of tyrosine kinase receptors, including the insulin receptor (Goldwaser et al. 2000; Shechter et al. 1995; Shisheva and Shechter 1993). In vertebrates, a major process regulated by insulin (and insulin-like growth factor 1) is linear bone growth (McCarthy et al. 2000; Moriyama et al. 2000). Vanadate was also shown to exhibit strong metabolic and mitogenic effects, as demonstrated by in vitro studies using mammalian bone-derived cell lines (and also using rat calvaria and chondrocyte primary cultures) (Canalis 1985a; Kato et al. 1987; Lau et al. 1988). These effects have been extensively studied using two mammalian cell lines, MC3T3-E1 and UMR106, and important features, such as tyrosine phosphorylation and activation of signalling mechanisms, have been characterized (Barrio and Etcheverry 2006; Cortizo and Etcheverry 1995; Salice et al. 1999). Although repetitively studied in mammals, vanadate effects have not been investigated in marine vertebrates (e.g. fish and amphibians), despite being recognized as the second most abundant transition metal in seawater (Rehder 2003).

In this paper, we describe the effects of two different vanadate solutions on the growth and mineralization performances of a gilthead seabream bone-derived cell line (VSa13) recently developed in our laboratory (Pombinho et al. 2004) and capable of mineralizing its extracellular matrix.

\section{Materials and methods}

Dulbecco's modified Eagle medium (DMEM), fetal bovine serum (FBS), antibiotics (penicillin and streptomycin), antimycotic (fungizone), trypsinEDTA solution and L-glutamine were purchased from Invitrogen. Tissue culture dishes were purchased from 
Sarstedt or Nunc. CellTiter 96 non-radioactive proliferation assay kit was purchased from Promega. All other reagents were purchased from Sigma-Aldrich unless otherwise stated.

Cell culture maintenance

Cultured cells were maintained in DMEM supplemented with $1 \%$ penicillin-streptomycin, $1 \%$ fungizone, $2 \mathrm{mM} \mathrm{L-glutamine}$ and $10 \% \mathrm{FBS}$, and incubated at $33^{\circ} \mathrm{C}$ in a $10 \% \mathrm{CO}_{2}$ humidified atmosphere. Confluent cell cultures were divided (1:2) every 3-4 days using trypsin-EDTA solution.

Vanadate solution preparation

Metavanadate stock solution (50 mM, pH 6.7) was prepared from ammonium metavanadate $\left(\mathrm{NH}_{4} \mathrm{VO}_{3}\right)$. Decavanadate stock solution was obtained by adjusting the $\mathrm{pH}$ of the former solution to 4.0, as described elsewhere (Aureliano and Madeira 1994). The acquired characteristic orange color in decavanadate solution upon acidification reveals the presence of decameric vanadate species $\left(\mathrm{V}_{10}\right)$. Decavanadate stock solution was always adjusted to $\mathrm{pH} 7.0$ immediately before using it. Both vanadate solutions were stored at $4^{\circ} \mathrm{C}$. Although total vanadate concentration does not change, note that in case of decavanadate solutions the concentration in decameric vanadate species was effectively reduced 10-fold, meaning that stock decavanadate solutions contain $5 \mathrm{mM}$ decameric vanadate species. However, vanadate concentrations are always given for monomeric vanadate, i.e. total vanadate.

\section{Characterization of vanadate solutions}

The composition of both vanadate solutions was analysed by ${ }^{51} \mathrm{~V}$ Nuclear Magnetic Resonance (NMR) spectroscopy, as described elsewhere (Aureliano and Madeira 1994). Briefly, the composition of vanadate solutions upon dilution into DMEM was analysed in a Bruker AM-400 spectrometer at 105.2 MHz equipped with a 5-mm multinuclear inverse probe, using a $90^{\circ}$ pulse Fourier transform technique. Spectra were acquired at room temperature using $0.5 \mathrm{ml}$ of vanadate samples in the medium, containing at least $10 \% \mathrm{D}_{2} \mathrm{O}$, under the following conditions: spectral width $45,455 \mathrm{~Hz}$, accumulation time $0.05 \mathrm{~s}$ and relaxation delay $0.01 \mathrm{~s} .{ }^{51} \mathrm{~V}$ NMR chemical shifts are reported relative to an external reference of $\mathrm{VOCl}_{3}(0 \mathrm{ppm})$. The relative areas of the several free or/and bound vanadate resonances were integrated and the line widths were obtained after subtracting the value $(20 \mathrm{~Hz})$ used in line broadening. The concentration of each vanadate oligomer $V_{x}$ was calculated from the fractions of the total integrated areas observed in the recorded spectra as described (Equation 1). The symbol $A$ corresponds to the area measured for the $x$ vanadate species with the $n$ aggregation number (number of vanadium atoms), $A_{t}$, the sum of measured areas and $\left[V_{t}\right]$ corresponds to total vanadate concentration.

$\left[V_{x}\right]=\frac{A_{x}}{A_{t}} \times \frac{\left[V_{t}\right]}{n}$

The calculated concentrations of vanadate oligomers were reproducible within $2-4 \%$. For quantitative measurements, all spectra parameters were kept constant. Vanadate concentrations are always given for monomeric vanadate, i.e. total vanadium.

Unlike metavanadate, decavanadate solutions are unstable. The partial deoligomerization of decameric vanadate species present at the decavanadate solutions upon dilution in DMEM medium was analysed by ultraviolet/visible spectroscopy at $400 \mathrm{~nm}$, as described elsewhere (Soares et al. 2006).

\section{Cell viability measurement}

Cytotoxic and proliferative effects of vanadate oligomers on VSa13 cells were assessed through cell viability analysis using the CellTiter 96 non-radioactive proliferation assay kit according to the manufacturer's instructions. Tetrazolium reagent (3-(4,5-dimethylthiazol2-yl)-5-(3-carboxy-methoxyphenyl)-2-(4-sulfophenyl)2H-tetrazolium; inner salt, MTS) and the electron-coupling reagent, phenazine methosulfate, were mixed in solution in a 20:1 proportion. Once added to cell culture, MTS is reduced into formazan by the dehydrogenase enzyme found in metabolically active cells. Formazan formation, which is proportional to the number of living cells (Malich et al. 1997), was followed at $490 \mathrm{~nm}$ in 96-well tissue culture dishes. Incubation with $20 \mu \mathrm{l}$ of reagent mixture during $1 \mathrm{~h}$ was determined to be the optimal conditions for VSa13 cell viability measurement. Vanadate cytotoxic effects were studied in confluent cell cultures (approximately $1.7 \times 10^{4}$ cells/ well) while effects on cell proliferation were investi- 
gated in low-density cell cultures (starting from $1.5 \times 10^{3}$ cells/well).

Vanadium accumulation measurement

Cells were cultured for $0,1,2,4,8$ and $24 \mathrm{~h}$ in the presence of $10 \mu \mathrm{M}$ metavanadate or decavanadate. At appropriate times, cell cultures were washed three times with phosphate-buffered saline (PBS), supplemented with $1 \mathrm{ml}$ of MilliQ water (Millipore) and placed at $-80^{\circ} \mathrm{C}$ for $10 \mathrm{~h}$. Frozen cells were thawed at room temperature for $15 \mathrm{~min}$, collected using a cell scraper and transferred into a 2-ml microcentrifuge tube. Cell culture dishes were washed once with $1 \mathrm{ml}$ of MilliQ water and washing solution was transferred into the microcentrifuge tube containing the initial cell extract. Total protein content was quantified from cell extracts using Bradford reagent. Samples were then digested at $100^{\circ} \mathrm{C}$ with $30 \mu \mathrm{l}$ of $65 \% \mathrm{HNO}_{3}$ and final solid residues dissolved in $5 \% \mathrm{HCl}$ solution. Vanadium concentration was determined by atomic absorption spectrometry analysis using a GBC Avanta atomic absorption spectrometer equipped with a GBC GF 3000 graphite furnace system and a GBC PAL 3000 auto sampler working at a furnace program of $63 \mathrm{~s}$ with an argon gas flow of $3.0 \mathrm{~L} / \mathrm{min}$. The vanadium lamp was operated at $318.2 \mathrm{~nm}$, with slit width of $0.2 \mathrm{~nm}$, and the instrument was calibrated against a series of solutions containing 12.5, 25, 37.5 and $50 \mathrm{ppb}$ of vanadium. Calibrating standards were obtained by successive dilutions of a standard solution of vanadium $1002 \pm 2 \mathrm{mg} / \mathrm{L}$ (Merck). The detection and quantification limits of the instrument for these analysis conditions, determined according to ISO 8466-1, were 5 and $11 \mathrm{ppb}$, respectively.

Extracellular matrix mineralization and nodule detection

Cells were seeded in 24-well plates at $2 \times 10^{4}$ cells/well and cultured in DMEM supplemented with 10\% FBS. To induce ECM mineralization, confluent cultures received medium supplemented with $50 \mu \mathrm{g} / \mathrm{mL}$ of L-ascorbic acid (vitamin C), $10 \mathrm{mM} \beta$-glycerophosphate and $4 \mathrm{mM} \mathrm{CaCl}_{2}$ up to 4 weeks. Wherever appropriate, cells were washed three times with PBS at $4^{\circ} \mathrm{C}$, fixed with $10 \%$ formaldehyde (in PBS) for $1 \mathrm{~h}$ at $4^{\circ} \mathrm{C}$, washed three times with distilled water, then incubated with $5 \%$ silver nitrate for $30 \mathrm{~min}$ under ultraviolet light. Relative levels of ECM mineralization were determined by densitometric methods using Quantity 1 software (Bio-Rad).

Statistical analysis

The data were presented as average and standard deviation of measurements taken at least in three separate experiments. Statistical significance of data was analysed wherever indicated by Student $t$ test or analysis of variance (ANOVA) analysis. Differences were considered to be significant at $P<0.05$.

\section{Results}

Vanadate solutions characterization in DMEM

${ }^{51} \mathrm{~V}-\mathrm{NMR}$ spectroscopy of 1 and $5 \mathrm{mM}$ decavanadate solutions in DMEM, at $\mathrm{pH}$ 7.0, revealed three signals attributed to three specific vanadium atoms in V10 structure: V10A at $-515 \mathrm{ppm}, \mathrm{V} 10 \mathrm{~B}$ at $-498 \mathrm{ppm}$ and V10C at -425 ppm (Fig. 1a). Conversely, in 1 and $5 \mathrm{mM}$ metavanadate solutions (Fig. 1a), detected signals ascribed to mono- (V1), di- (V2), tetra- (V4) and pentameric (V5) vanadate species, respectively, at $-556 \mathrm{ppm},-571 \mathrm{ppm},-579 \mathrm{ppm}$ and at $587 \mathrm{ppm}$ (Fig. 1a). Monomeric NMR signal is clearly broadened, with a half line-width value $(270 \mathrm{~Hz})$ approx. 3.4 -fold of normal value $(80 \mathrm{~Hz})$, probably caused by vanadate interactions with compounds present in DMEM such as glucose $(25 \mathrm{mM})$ and piruvate (1 $\mathrm{mM})$, or even interactions with several proteins also present in the medium. For each metavanadate concentration in DMEM (1 and $5 \mathrm{mM}$ ), different amounts of mono (V1), di (V2), tetra (V4) and pentameric (V5) species have been observed, that corresponded to different species profiles (Fig. 1b). While tetrameric species were predominant at $5 \mathrm{mM}$ metavanadate, monomeric vanadate was the major specie in the lower concentration (Fig. 1b). Conversely, decameric vanadate species present in the decavanadate solutions increased linearly with total vanadate concentration (Fig. 1c).

Although ${ }^{51} \mathrm{~V}$-NMR spectroscopy is an essential technique for the analysis of vanadate oligomers composition and interactions, approximately $1 \mathrm{~h}$ acquisition time was necessary to obtain a clear spectrum of $1 \mathrm{mM}$ decavanadate solution (Fig. 1a). 

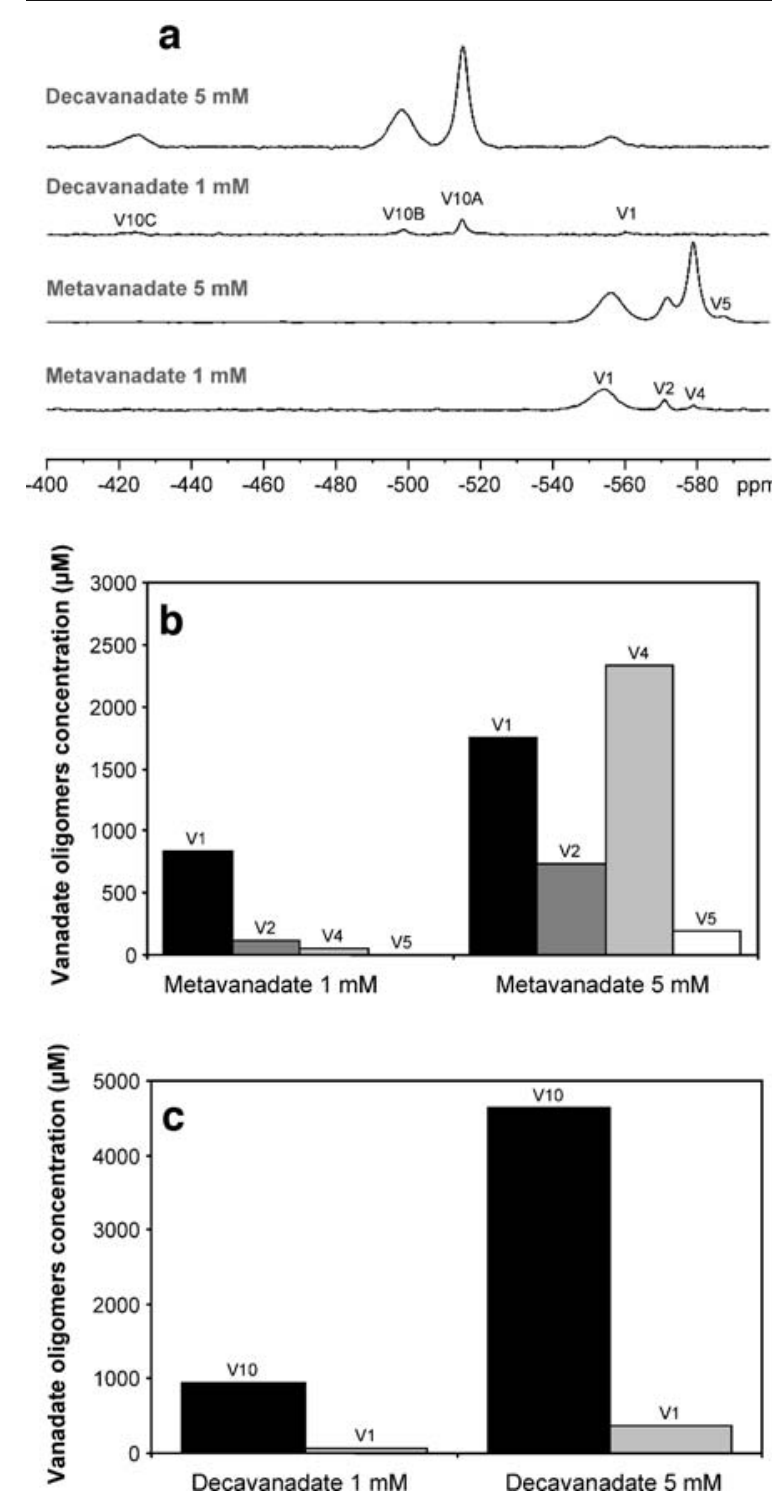

Fig. $1105.2 \mathrm{MHz}{ }^{51} \mathrm{~V}$ NMR spectra, at $22^{\circ} \mathrm{C}$, of two vanadate concentrations (total vanadate), namely, 1 and $5 \mathrm{mM}$ of decavanadate and metavanadate in DMEM, $\mathrm{pH}$ 7.1. (a) V1 and $\mathrm{V} 2$ signals correspond to monomeric $\left(\mathrm{H}_{2} \mathrm{VO}_{4}^{-}\right)$and dimeric $\left(\mathrm{HV}_{2} \mathrm{O}_{7}^{3-}\right.$ and $\left.\mathrm{H}_{2} \mathrm{~V}_{2} \mathrm{O}_{7}^{2-}\right)$ vanadate species, respectively, irrespective of the protonation state, whereas $\mathrm{V} 4$ and $\mathrm{V} 5$ correspond to cyclic tetrameric $\left(\mathrm{V}_{4} \mathrm{O}_{12}^{4-}\right)$ and pentameric $\left(\mathrm{V}_{5} \mathrm{O}_{15}^{5-}\right)$ vanadate species. $\mathrm{V} 10 \mathrm{~A}, \mathrm{~V} 10 \mathrm{~B}$ and $\mathrm{V} 10 \mathrm{C}$ signals correspond, respectively, to the $\mathrm{V}(2), \mathrm{V}(1)$ and $\mathrm{V}(3)$ vanadium atoms in the decameric vanadate specie $\left(\mathrm{V}_{10} \mathrm{O}_{28}^{6-}\right)$. The concentrations of each vanadium $(\mathrm{V})$ species for metavanadate (b) and decavanadate (c) solutions were calculated from the fractions of the total integrated areas observed in the spectra. For quantitative measurements, spectral parameters were kept constant and the spectra were normalized regarding $5 \mathrm{mM}$ decavanadate spectra
In this sense, ${ }^{51} \mathrm{~V}$-NMR spectroscopy is not adequate to follow the decomposition kinetics of decavanadate, in particular for vanadate concentrations lower than $1 \mathrm{mM}$. However, the disappearance of decameric vanadate species can be easily followed by ultraviolet/visible (UV/Vis) spectroscopy. Therefore, the stability of decameric species in DMEM was analysed by UV/Vis, at $33^{\circ} \mathrm{C}$, using a $250 \mu \mathrm{M}$ decavanadate solution (total vanadium concentration, meaning $25 \mu \mathrm{M}$ decameric vanadate species). It was observed that in DMEM, decameric species decompose through a first-order kinetic, with a half-life time of $150 \mathrm{~min}$ (not shown).

Long- and short-term exposure to meta- and decavanadate

Cytotoxicity of vanadate oligomers on VSa13 cells was tested in confluent cultures for either 15 days using concentrations ranging from 0 to $250 \mu \mathrm{M}$ (chronic toxicity) or $4 \mathrm{~h}$ using a concentration of $1 \mathrm{mM}$ (acute toxicity). Prolonged exposure to meta- or decavanadate similarly affected VSa13 cell viability (Fig. 2): treatments with concentrations up to $7.5 \mu \mathrm{M}$ did not decrease cell viability (a slight increase was even observed after 15 days), while treatments with concentrations from 10 to $250 \mu \mathrm{M}$ seriously affected cell viability, killing most of the cells at highest concentrations. On the contrary, short-term exposure to metaand decavanadate differentially affected VSa13 cell viability (Fig. 3): While $1 \mathrm{mM}$ decavanadate significantly reduced cell viability after 2 hours, $1 \mathrm{mM}$ metavanadate showed no effects. After 4 hours, both solutions significantly (according to ANOVA analysis) reduced the cell viability to levels approximate to $50 \%$. This observation suggests that decameric vanadate species, still present in culture medium after $2 \mathrm{~h}$, are likely to induce more toxicity effects than monomeric vanadate species, certainly the most abundant vanadate form found in culture medium after $4 \mathrm{~h}$ (half-life time of decavanadate in DMEM was estimated at $2.5 \mathrm{~h}$ ) upon decameric vanadate disintegration.

Stimulation of cell proliferation by vanadate

Vanadate effect on VSa13 cell proliferation rate was also investigated in dividing cultures (Fig. 4), and both metavanadate and decavanadate exhibited similar effects (thus, only metavanadate results are shown), i.e. a significant stimulation of proliferation rate was observed for $7.5 \mu \mathrm{M}$ concentration (accord- 

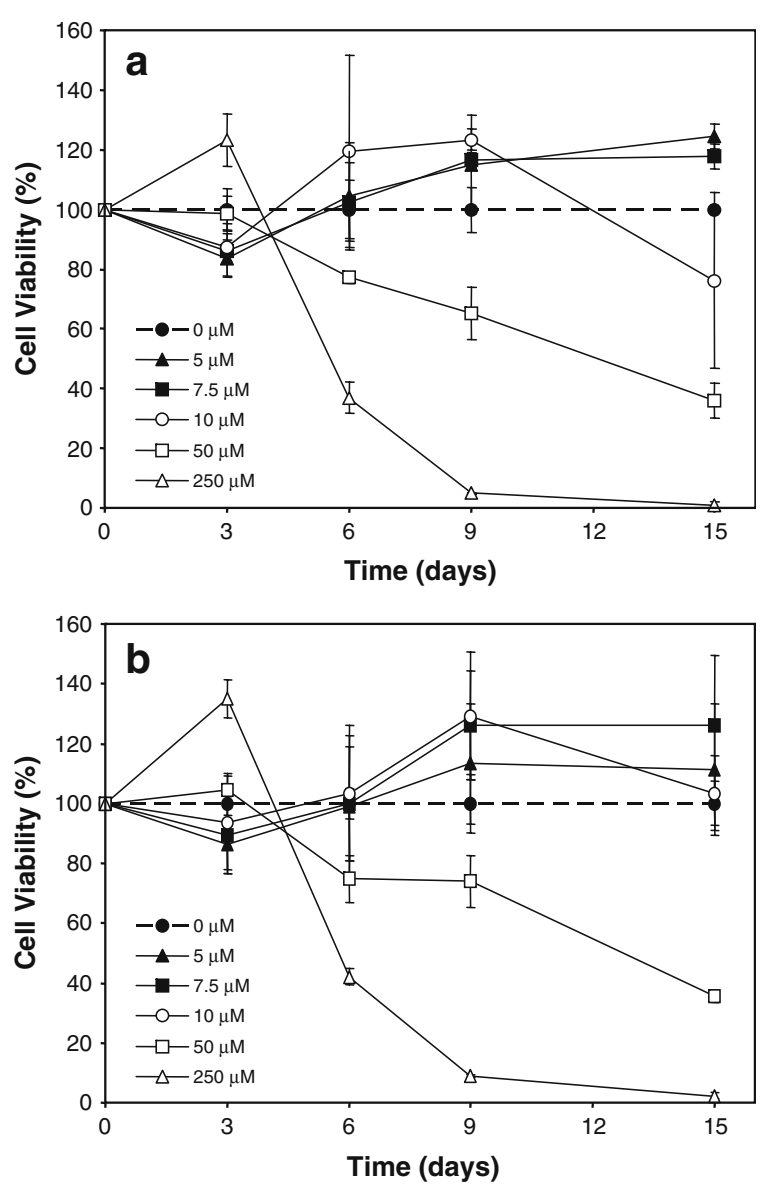

Fig. 2 Long-term effect of metavanadate and decavanadate on VSa13 cell viability. VSa13 cells were seeded in 96-well plates, grown in DMEM until confluence then treated with metavanadate (a) and decavanadate (b) using concentrations ranging from 5 to $250 \mu \mathrm{M}$. Cell viability was evaluated at appropriate times using MTS assay and is presented as the percentage of control value (set to $100 \%$ ). Values are the mean of at least three independent experiments

ing to ANOVA analysis). On the contrary, $10 \mathrm{nM}$ insulin (concentration used in mammalian bonederived cell line, Quarto et al. 1992), had no effect on cell proliferation (Fig. 4) suggesting that vanadate, despite proven insulin-mimetic properties, stimulates cell proliferation. Nevertheless, no effects were observed in cell proliferation using insulin concentrations up to $100 \mathrm{nM}$ (not shown).

Metavanadate and decavanadate exhibit different rates of accumulation in cells

The amount of vanadium accumulated within VSa13 cells was determined in confluent cultures treated with $10 \mu \mathrm{M}$ meta- or decavanadate for $0,1,2,4$, 8 and $24 \mathrm{~h}$ after subtraction of vanadium content measured in non-treated cells $(2.54 \pm 0.43 \mu \mathrm{g} \mathrm{V} / \mathrm{g}$ of protein) (Fig. 5). After $1 \mathrm{~h}$ of treatment, vanadium accumulation was higher in cells treated with metavanadate $(4.61 \pm 0.29 \mu \mathrm{g} \mathrm{V} / \mathrm{g}$ of protein) than in cells treated with decavanadate $(3.24 \pm 0.24 \mu \mathrm{g} \mathrm{V} / \mathrm{g}$ of protein), being the effect statistically significant (according to Student's $t$ test). A similar, but more pronounced, difference between meta- and decavanadate-related vanadium accumulations was observed after $2 \mathrm{~h}$ of treatment $(6.85 \pm 0.4 \mu \mathrm{g}$ and $3.95 \pm 0.1 \mu \mathrm{g}$ $\mathrm{V} / \mathrm{g}$ of protein, respectively). Longer incubation times resulted in a higher accumulation of vanadium (approximately 18-fold increase above control value after $24 \mathrm{~h}$ ), but no significant differences were observed between metavanadate and decavanadate treated cells, as expected. These results suggest that monomeric species enter VSa13 cells and accumulate more easily than decameric species and that accumulation rates become similar only when most of decameric molecules are decomposed (half-life time of decavanadate in DMEM was estimated at $2.5 \mathrm{~h}$ ).

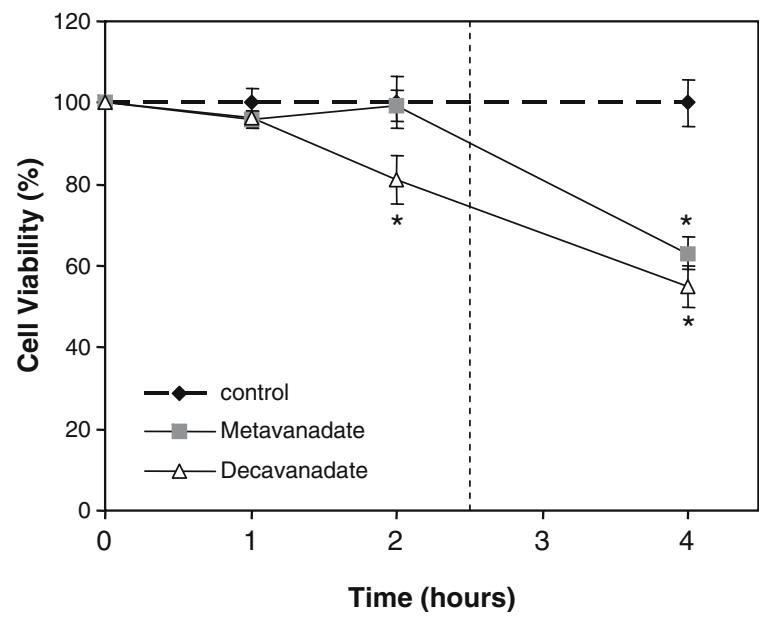

Fig. 3 Short-term effect of metavanadate and decavanadate on VSa13 cell viability. VSa13 cells were seeded in 96-microwell plates, grown in DMEM until confluence then treated with $1 \mathrm{mM}$ metavanadate and decavanadate. Cell viability was evaluated at appropriate times using MTS assay and is presented as the percentage of control value (set to $100 \%$ ). Values are the mean of at least three independent experiments. Asterisk indicates that values are statistically different in comparison to the respective control $(P<0.05$ one-way ANOVA). Dashed line indicates the half-life of decavanadate in DMEM estimated at $2.5 \mathrm{~h}$ 


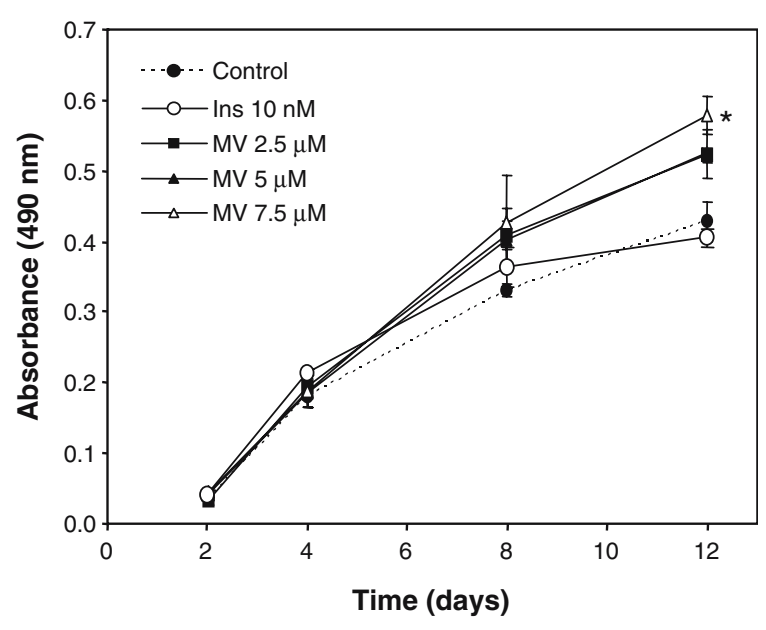

Fig. 4 Effect of metavanadate and insulin on VSa13 cell proliferation. VSa13 cells were seeded in 96-well plates at $1.5 \times$ $10^{3}$ cell/well then treated with metavanadate using concentrations ranging from 2.5 to $7.5 \mu \mathrm{M}$ or $10 \mathrm{nM}$ insulin. Cell proliferation was evaluated at appropriate times using MTS assay. Values are the mean of at least three independent experiments. Asterisk indicates that values are statistically different in comparison to the respective control $(P<0.05$ oneway ANOVA)

\section{Discussion}

The effects of vanadium on bone biology have been extensively studied in several mammalian in vivo and in vitro systems (Etcheverry and Cortizo 1998; Shechter 1990), but, to our knowledge, no studies have been performed using bone-derived systems of aquatic vertebrate origin. In this study, we analyse, for the first time, the effects different vanadate oligomers have on bone-derived cell line mineralization. However, the composition of vanadate solutions is very sensitive to vanadate concentration, $\mathrm{pH}$, buffer and other compounds used in biochemical studies. Therefore, it is of primary importance to precisely characterise the species that can interact with a system before attempting to understand the effects promoted by vanadate solutions. Unlike metavanadate containing several oxovanadates, decavanadate solutions contain decameric vanadate species (V10). However, $\mathrm{V} 10$ is unstable and decomposes into monomeric vanadate with a half-life time of above $2 \mathrm{~h}$ in DMEM. In this regard, effects of decavanadate were always compared with those of metavanadate.

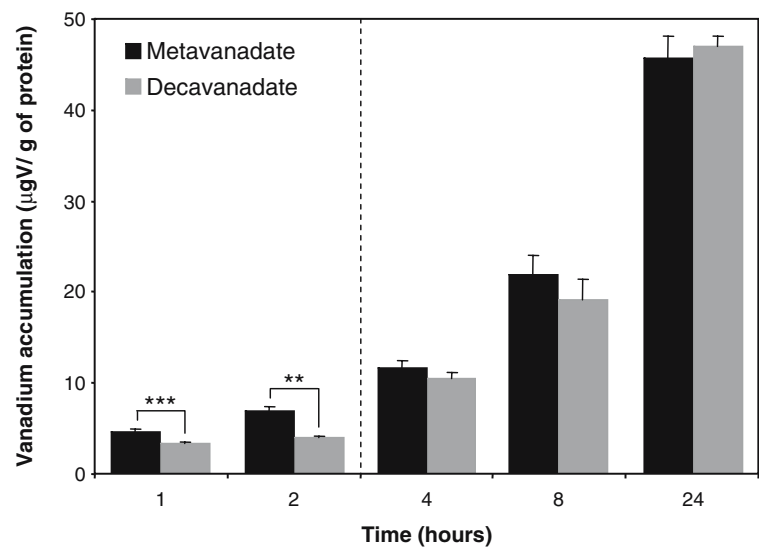

Fig. 5 Vanadium accumulation in VSa13 cells upon vanadate solutions exposure. VSa13 cells were seeded in $100-\mathrm{mm}$ plates, grown in DMEM until confluence then treated with $10 \mu \mathrm{M}$ metavanadate or decavanadate. At appropriate times, vanadium content was determined by atomic absorption from cellular extract and normalized with protein content. Vanadium content measured in non-treated samples $(2.54 \pm 0.43 \mu \mathrm{g} \mathrm{V} / \mathrm{g}$ of protein) was subtracted from each value. Asterisks indicate statistically significant differences between metavanadate and decavanadate according to Student's test $(* * p<0.005$ and $* * * p<0.001)$. Values are the mean of at least three independent experiments. Dashed line indicates the half-life of decavanadate in DMEM estimated at $2.5 \mathrm{~h}$ 


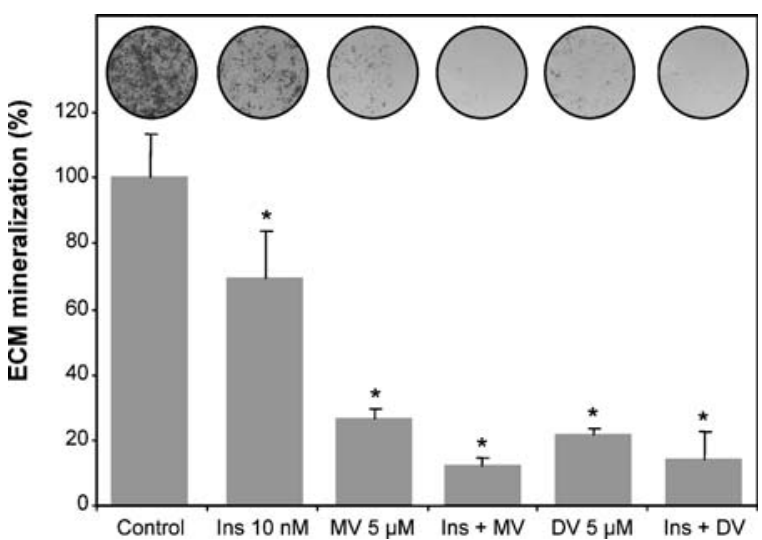

Fig. 6 Effect of metavanadate, decavanadate and insulin on extracellular matrix mineralization. VSa13 cells were seeded in 24-well plates, grown in DMEM until confluence then treated for mineralization. Mineralizing cultures were subsequently treated with $10 \mathrm{nM}$ insulin (Ins), $5 \mu \mathrm{M}$ metavanadate (MV), $5 \mu \mathrm{M}$ decavanadate (DV), metavanadate and insulin (Ins+MV), decavanadate and insulin (Ins + DV) or left untreated. Mineral deposition was revealed by von Kossa staining and evaluated by densitometric analysis. Pictures of von Kossa-stained VSa13 cells are presented above each treatment. Values are the mean of at least three independent experiments. Asterisk indicates that values are statistically different in comparison to the respective control $(P<0.05$ one-way ANOVA)

Monomeric and decameric vanadate species affect VSa13 cells differently

Prolonged exposure to low levels of meta- and decavanadate similarly affected VSa 13 cell viability and proliferation, whereas short-term exposure to high levels of decavanadate was more toxic than that of metavanadate. In DMEM, decavanadate decomposes into monomeric species with a half-life time of $\sim 150 \mathrm{~min}$, suggesting that its long-term effects are most probably caused by newly formed monomeric species (as for metavanadate), whereas short-term effects are likely caused by decameric vanadate species. Considering that decavanadate solution contains 10 times less molecules (particularly in shorter exposure times, in which decameric species are predominant) than metavanadate (in which monomeric species are predominant), short-term toxicity of decavanadate is even more remarkable. This result is consistent with previous observations that decavanadate and metavanadate produce different oxidative stress levels in cardiac muscle in toadfish and gilthead seabream (Aureliano et al. 2002; Soares et al. 2007) and interact differently in vitro with specific proteins such as myosin and sarcoplasmic reticulum $\mathrm{Ca}^{2+}$ ATPase (Aureliano and Madeira 1994; Tiago et al. 2004; Aureliano and Gândara 2005). Prolonged exposure to low levels of vanadate resulted in an apparent increase in cell viability/number, an effect that was previously observed in mammalian bonederived cell cultures (MC3T3E1 and UMR106) (Barrio et al. 1997; Cortizo et al. 2000; Etcheverry et al. 1997; Salice et al. 1999) and attributed to its ability to increase phosphotyrosine protein levels and to inhibit phosphotyrosine phosphatases, thus regulating growth signalling pathways.

Although cellular accumulation of metavanadate has been previously demonstrated in mammalian systems, e.g. bovine kidney and Caco-2 cells (Bracken et al. 1985; Yang et al. 2004), this process has never been analysed in a comparative study with decavanadate. We present evidences that vanadium differently accumulates in VSa13 cells treated with metavanadate or decavanadate solutions (decavanadate treatments resulted in significantly lower vanadium accumulation at 1 and $2 \mathrm{~h}$; Fig. 5), which was probably caused by an inexistent or a less efficient uptake mechanism for decameric species.

Vanadate stimulates VSa13 cell proliferation

Both vanadate oligomers exhibited a similar effect on VSa13 growth rate, i.e. a stimulation of cell proliferation. A similar effect has been reported in mammalian bone-derived cell lines and associated with the activation of the insulin receptor. Insulin was shown not to affect VSa13 cell proliferation, indicating that either insulin receptor/signalling pathway is absent in VSa13 cells (this hypothesis was later ruled out after insulin was shown to affect ECM mineralization) or vanadate stimulating effect is not mediated through insulin signalling pathway. Several studies have already proposed cytosolic tyrosine kinase receptor as a mediator of vanadate proliferative effect (Shisheva and Shechter 1992, 1993), and we propose that a similar mechanism could occur in VSa13 cells.

Inhibition of ECM mineralization by vanadate

Mineralization of VSa13 extracellular matrix was mildly reduced by insulin, strongly inhibited by vanadate, regardless of its oligomerization (monomeric or decameric), and even more strongly inhibited 
when both insulin and vanadate were present. Two important regulatory effects have been associated with vanadium osteogenic action in mammalian bonederived cells: the inhibition of alkaline phosphatase activity and the stimulation of type I collagen synthesis (Barrio and Etcheverry 2006; Canalis 1985b; Lau et al. 1988). Both processes are essential to the correct mineralization of the extracellular matrix of bone cells (Murshed et al. 2005), and it is likely that vanadium effect on vertebrate bone depends on the equilibrium between its stimulatory and inhibitory properties. Vanadium derivatives were previously shown to specifically activate insulinassociated pathways (i.e. MAPK and PI-3K pathways) through phosphorylation of common intermediates such as extracellular signal-regulated kinase (ERK) (Barrio and Etcheverry 2006). Moreover, vanadium proliferative effect was reverted by specific inhibitors of insulin-associated pathways. In one of those studies, vanadyl (IV)-ascorbate, a vanadium complex, significantly increased the rate and extent of mineral deposition within the ECM of mouse MC3T3-E1 bone-derived cells and stimulated type I collagen synthesis (Cortizo et al. 2006). These effects were apparently related to both MAPK and PI-3K pathways activation and ERK increased phosphorylation. In another study, it was described that the alkaline phosphatase activity is inhibited in MC3T3-E1 cells by a trehalose vanadyl complex independently of regular insulin-associated pathways. Based on published results, we suggest that vanadate inhibitory effect on VSa13 ECM mineralization could be associated with either direct interference of vanadium into key processes such as alkaline phosphatase activity, or indirect interference of vanadium into insulin-associated pathways. Recently, it was shown that the ECM mineralization of MC3T3-E1 cells is inhibited by platelet-derived growth factor through ERK activation (Kono et al. 2007). This result is, on one hand, contradictory to a previous observation where ECM mineralization of MC3T3-E1 cells was stimulated by vanadium through ERK activation (Cortizo et al. 2006), but, on the other hand, in total agreement with the inhibition of VSa13 ECM mineralization by vanadate, possibly through ERK activation. The characterisation of the mechanisms involved in vanadate inhibitory effect in VSa13 cell line will need to be investigated in future studies.

\section{Conclusion}

Vanadate was shown here to accumulate within VSa13 bone-derived cells, stimulating growth performance through insulin-independent mechanisms and preventing ECM mineralization probably through multiple processes involving regulation that may or may not depend on the activation of insulin-stimulated pathways. The presence of decameric vanadate species was also shown to produce differences (accumulation and cytotoxicity) between meta- and decavanadate in short-term exposure while acting similarly in prolonged exposure caused eventually by the decomposition of decavanadate into other oligomers. VSa13 cells were shown to be a suitable model to study vanadium mechanisms of action in vertebrate bone development and to be a good alternative to mammalian systems.

Acknowledgements The authors thank Dr. Hélio Martins from the Faculty of Sciences and Technology (FCT) of the University of Algarve for his technical help in the course of atomic absorption spectrometry experiments. Thanks also to J.J.G. Moura, REQUIMTE, New University of Lisbon, for the esteemed collaboration in the NMR studies. DMT was the recipient of a Ph.D. fellowship (BD/12773/2003) from the Portuguese Science and Technology Foundation.

\section{References}

Amado AM, Aureliano M, Ribeiro-Claro PJA, Teixeira-Dias JJ. Combined Raman and V-51 NMR spectroscopic study of vanadium (V) oligomerization in aqueous alkalinesolutions. J Raman Spectrosc 1993;24:699-703.

Anke M. Vanadium - An element both essential and toxic to plants, animals and humans? Anal Real Acad Nac Farm 2004;70:961-99.

Aureliano M, Madeira VM. Interactions of vanadate oligomers with sarcoplasmic reticulum $\mathrm{Ca}(2+)$-ATPase. Biochim Biophys Acta 1994;1221:259-71.

Aureliano M, Gandara RM. Decavanadate effects in biological systems. J Inorg Biochem 2005;99:979-85.

Aureliano M, Joaquim N, Sousa A, Martins H, Coucelo JM. Oxidative stress in toadfish (Halobactrachus didactylus) cardiac muscle. Acute exposure to vanadate oligomers. J Inorg Biochem 2002;90:159-65.

Barrio DA, Etcheverry SB. Vanadium and bone development: putative signaling pathways. Can J Physiol Pharmacol 2006;84:677-86.

Barrio DA, Braziunas MD, Etcheverry SB, Cortizo AM. Maltol complexes of vanadium (IV) and (V) regulate in vitro alkaline phosphatase activity and osteoblast-like cell growth. J Trace Elem Med Biol 1997;11:110-5. 
Bracken WM, Sharma RP, Elsner YY. Vanadium accumulation and subcellular distribution in relation to vanadate induced cytotoxicity in vitro. Cell Biol Toxicol 1985;1:259-68.

Canalis E. Effect of sodium vanadate on deoxyribonucleic acid and protein synthesis in culture rat calvariae. Endocrinology 1985a; $116: 855-62$.

Canalis E. Effect of sodium vanadate on deoxyribonucleic acid and protein syntheses in cultured rat calvariae. Endocrinology 1985b;116:855-62.

Cheatham B, Kahn CR. Insulin action and the insulin signaling network. Endocr Rev 1995;16:117-42.

Cohick WS, Clemmons DR. The insulin-like growth factors. Annu Rev Physiol 1993;55:131-53.

Cortizo AM, Etcheverry SB. Vanadium derivatives act as growth factor-mimetic compounds upon differentiation and proliferation of osteoblast-like UMR106 cells. Mol Cell Biochem 1995;145:97-102.

Cortizo AM, Bruzzone L, Molinuevo S, Etcheverry SB. A possible role of oxidative stress in the vanadium-induced cytotoxicity in the MC3T3E1 osteoblast and UMR106 osteosarcoma cell lines. Toxicology 2000;147:89-99.

Cortizo AM, Molinuevo MS, Barrio DA, Bruzzone L. Osteogenic activity of vanadyl(IV)-ascorbate complex: evaluation of its mechanism of action. Int J Biochem Cell Biol 2006;38:1171-80.

Crans DC, Smee JJ, Gaidamauskas E, Yang L. The chemistry and biochemistry of vanadium and the biological activities exerted by vanadium compounds. Chem Rev 2004;104:849-902.

Dubyak GR, Kleinzeller A. The insulin-mimetic effects of vanadate in isolated rat adipocytes. Dissociation from effects of vanadate as a $(\mathrm{Na}+-\mathrm{K}+)$ ATPase inhibitor. J Biol Chem 1980;255:5306-12.

Etcheverry SB, Cortizo AM. Bioactivity of vanadium compounds on cells in culture. In: Nriagu JO, editor. Vanadium in the environment. New York: John Wiley \& Sons; 1998.

Etcheverry SB, Apella MC, Baran EJ. A model study of the incorporation of vanadium in bone. $\mathrm{J}$ Inorg Biochem 1984;20:269-74.

Etcheverry SB, Crans DC, Keramidas AD, Cortizo AM. Insulinmimetic action of vanadium compounds on osteoblast-like cells in culture. Arch Biochem Biophys 1997;338:7-14.

Goldwaser I, Gefel D, Gershonov E, Fridkin M, Shechter Y. Insulin-like effects of vanadium: basic and clinical implications. J Inorg Biochem 2000;80:21-5.

Heyliger CE, Tahiliani AG, McNeill JH. Effect of vanadate on elevated blood glucose and depressed cardiac performance of diabetic rats. Science 1985;227:1474-7.

Kato Y, Iwamoto M, Koike T, Suzuki F. Effect of vanadate on cartilagematrix proteoglycan synthesis in rabbit costal chondrocyte cultures. J Cell Biol 1987;104:311-9.

Kono SJ, Oshima Y, Hoshi K, Bonewald LF, Oda H, Nakamura K, et al. Erk pathways negatively regulate matrix mineralization. Bone 2007;40:68-74.

Lau KH, Tanimoto H, Baylink DJ. Vanadate stimulates bone cell proliferation and bone collagen synthesis in vitro. Endocrinology 1988;123:2858-67.
LeRoith D. Insulin-like growth factor I receptor signalingoverlapping or redundant pathways? Endocrinology 2000; 141:1287-8.

Malich G, Markovic B, Winder C. The sensitivity and specificity of the MTS tetrazolium assay for detecting the in vitro cytotoxicity of 20 chemicals using human cell lines. Toxicology 1997;124:179-92.

McCarthy TL, Ji C, Centrella M. Links among growth factors, hormones, and nuclear factors with essential roles in bone formation. Crit Rev Oral Biol Med 2000;11:409-22.

Meyerovitch J, Farfel Z, Sack J, Shechter Y. Oral administration of vanadate normalizes blood glucose levels in streptozotocin-treated rats. Characterization and mode of action. J Biol Chem 1987;262:6658-62.

Moriyama S, Ayson FG, Kawauchi H. Growth regulation by insulin-like growth factor-I in fish. Biosci Biotechnol Biochem 2000;64:1553-62.

Murshed M, Harmey D, Millan JL, McKee MD, Karsenty G. Unique coexpression in osteoblasts of broadly expressed genes accounts for the spatial restriction of ECM mineralization to bone. Genes Dev 2005;19:1093-104.

Nielsen FH, Uthus EO. The essentiality and metabolism of vanadium. In: Chasteen ND, editor. Vanadium in biological systems. Boston: Kluwer Academic Publishers; 1990.

Pombinho AR, Laize V, Molha DM, Marques SM, Cancela ML. Development of two bone-derived cell lines from the marine teleost Sparus aurata; evidence for extracellular matrix mineralization and cell-type-specific expression of matrix Gla protein and osteocalcin. Cell Tissue Res 2004;315:393-406.

Quarto R, Campanile G, Cancedda R, Dozin B. Thyroid hormone, insulin and glucocorticoids are sufficient to support chondrocyte differentiation to hypertrophy: a serum-free analysis. J Cell Biol 1992;119:989-95.

Rehder D. The coordination chemistry of vanadium as related to its biological functions. Coord Chem Rev 1999; 182:297-322.

Rehder D. Biological and medicinal aspects of vanadium. Inorg Chem Commun 2003;6:604-17.

Salice VC, Cortizo AM, Gomez Dumm CL, Etcheverry SB. Tyrosine phosphorylation and morphological transformation induced by four vanadium compounds on MC3T3E1 cells. Mol Cell Biochem 1999;198:119-28.

Shechter Y. Perspective in diabetes: insulin-mimetic effects of vanadate. Possible implications for future treatment of diabetes. Diabetes 1990;39:1-5.

Shechter Y, Karlish SJ. Insulin-like stimulation of glucose oxidation in rat adipocytes by vanadyl (IV) ions. Nature 1980;284:556-8.

Shechter Y, Li J, Meyerovitch J, Gefel D, Bruck R, Elberg G, et al. Insulin-like actions of vanadate are mediated in an insulin-receptor-independent manner via non-receptor protein tyrosine kinases and protein phosphotyrosine phosphatases. Mol Cell Biochem 1995;153:39-47.

Shisheva A, Shechter Y. A cytosolic protein tyrosine kinase in rat adipocytes. FEBS Lett 1992;300:93-6. 
Shisheva A, Shechter Y. Role of cytosolic tyrosine kinase in mediating insulin-like actions of vanadate in rat adipocytes. J Biol Chem 1993;268:6463-9.

Soares SS, Martins H, Aureliano M. Vanadium distribution following decavanadate administration. Arch Environ Contam Toxicol 2006;50:60-4.

Soares SS, Martins H, Duarte RO, Moura JJG, Coucelo J, Gutiérrez-Merino C, et al. Vanadium distribution, lipid peroxidation and oxidative stress markers upon decava- nadate in vivo administration. J Inorg Biochem 2007; 101:80-8.

Tiago T, Aureliano M, Gutierrez-Merino C. Decavanadate binding to a high affinity site near the myosin catalytic centre inhibits F-actin-stimulated myosin ATPase activity. Biochemistry 2004;43:5551-61.

Yang XG, Yang XD, Yuan L, Wang K, Crans DC. The permeability and cytotoxicity of insulin-mimetic vanadium compounds. Pharm Res 2004;21:1026-33. 